\title{
Laborvizsgálat jelentősége implantációs betegeknél
}

\author{
DR. NAGY-CSOMA LUCA*, DR. IVÁNYI DÓRA**, DR. KIVOVICS PÉTER ${ }^{\star \star}$, DR. NÉMETH ORSOLYA
}

\begin{abstract}
A fogászati implantáció elterjedésével előtérbe kerülnek az implantációval kapcsolatos szövődmények vizsgálatai. Az egyik gyakori szövődmény az implantátum körüli szöveteket érintő gyulladás. Ennek kialakulásában számos tényező játszik szerepet, többek közt az általános egészségi állapotot befolyásoló betegségek, például a cukorbetegség, hiperlipidémia és egyéb szisztémás betegségek [1]. Kutatásunk célja a vérvizsgálat - mint az implantációt megelőző szűrővizsgálat - effektivitásának felmérése és alkalmazása a periimplantáris gyulladások prevenciójában.

Vizsgálataink során 33 beteg teljes fogászati státusz felvételét és nagy rutinlabor eredményeit vetettünk össze. Az adatokat Microsoft Excel (Remond, Washington, Egyesült Államok) program segítségével értékeltük. A vizsgált betegek $81,8 \%$-a szenvedett részleges foghiányban, közülük 66,7\%-nál volt parodontális csontelváltozás diagnosztizálható orthopantomogram felvétel alapján. A betegpopuláció 21,2\%-ának volt magas az éhomi vércukorszintje, 51,5\%-nak pedig megnövekedett a vérzsír értéke. Emellett megvizsgáltuk a parodontális érintettség és a laboreltérések együttes előfordulási gyakoriságát is. Magas vércukorszint és a parodontális érintettség a betegek $6,1 \%$-ánál, parodontális érintettség és a magas gyulladásos paraméter a betegek $21,2 \%$-ánál volt egyszerre megfigyelhető. A periimplantáris gyulladások kialakulásának egyik rizikófaktora a nem vagy rosszul kezelt cukorbetegség. A hiperlipidémia negatívan befolyásolja a periimplantáris szövetek lokális immunreakcióit és az implantáció hosszútávú sikerességét befolyásoló csontintegrációt. Bármely általános rizikófaktor, parodontális érintettséggel együtt fokozott kockázatot jelent az implantáció során, ezáltal fontos szerepe van ezeknél a pácienseknél a rizikóanalízisnek és a rendszeres kontrollvizsgálatnak. A Fogászati és Szájsebészeti Oktató Intézet álláspontja szerint a vérvizsgálat már az implantációt megelőzően alkalmas az általános rizikófaktorok kiszürésére.
\end{abstract}

Kulcsszavak: Laborvizsgálat, vérvizsgálat, primer prevenció, periimplantitisz, cukorbetegség, hiperlipidémia

\section{Bevezetés}

A vérkép analízise számos fontos információval támogathatja a fogorvost az egyre gyakoribbá váló fogászati implantációs beavatkozások esetében. A beavatkozások gyakoriságának növekedésével előtérbe kerülnek a beavatkozások okozta szövődmények is [2]. Az implantációval kapcsolatos komplikációk lehetnek korai és késői szövődmények [3].

Korai komplikációként megemlítendők azok az állapotok, amelyek a beavatkozás során vagy rögtön utána jelentkeznek, mint például a komoly vérzések, lágy-, illetve keményszöveti sérülések és idegsérülés stb. [4]. Idegsérülés esetében előfordulhat az alsó állcsonton végzett mútét során a nervusz alveolárisz inferior sérülése, ha maga az implantátum eléri az idegcsatornát vagy esetleg betöri az idegcsatorna falát. Ekkor a páciensek leggyakoribb panasza az áll jellegzetes zsibbadása, de az idegsérülés mértékétől függően eltérő panaszok jelentkezhetnek [5]. Az idegképleteken kívül sérülhetnek a szomszédos fogak az implantá- tum behelyezésekor, amelyet a sérült fog gyökérkezelése, protetikailag való ellátása vagy eltávolítása követhet [6].

Késői szövődményeknek, amelyek a csontintegrációt követően alakulnak ki, két alcsoportját különböztetjük meg, ezek a biológiai- és a mechanikai szövődmények. Mechanikai szövődménynek tekintjük az implantátum vagy a rajta lévő pótlás bármilyen sérülését, törését. Biológiai szövődmény a periimplantáris mukozitisz és a periimplantitisz [7]. Definíció szerint a periimplantáris mukozitisz az enosszeális implantátumokat körbevevő lágy szövetek gyulladásos elváltozása, amely nem jár csontpusztulással. Előfordulását tekintve az implantátumot viselő páciensek 63,4\%-ánál, míg az implantátumok 30,7\%-ánál van jelen [8]. Az említett kórkép biofilm okozta reverzibilis állapot, amelyet a periimplantitisz előfutárának is tekintenek [9]. A periimplantitisz olyan patológiás állapot, amely az implantátumok körüli szövetekben fordul elő és a környező csont fokozatos pusztulása jellemez [10,11] (1. ábra). A periimplantitisz is gyakori szövődménynek tekinthető az implantáció 
során, a beültetett implantátumok 10\%-ánál és az implantáción átesett páciensek 20\%-ánál fordul elő [12]. Terápiájukat tekintve a korai diagnosztizálás mellett rendelkezésre állnak sebészi és nem sebészi lehetőségek is. Nem sebészi kezelések közül megemlítendő a mechanikus tisztítás, az antiszeptikus kezelés és az antibiotikumos terápia, amelyek megválasztása a tapadásveszteség mértékétől függően történik. Míg utolsó lehetőség lehet az implantátum eltávolítását megelőzően a periimplantitisz sebészi kezelése [13].

A periimplantáris gyulladások kialakulását több tényező segíti elő. Megkülönböztetünk lokális és általános rizikótényezőket [14]. A lokális rizikótényezők közé tartozik a dentális plakk, a parodontitisz, az implantátum körüli lágy- és keményszövetek nem megfelelő dimenziói és az implantátum és a felépítmény anyagi minősége, amennyiben plakkretentív [15]. Míg általános rizikótényezők közé sorolhatók az általános mútéti kontraindikációk, a dohányzás és a fej-nyak régiót érintő irradiációs terápia, emellett általános egészségi állapotot befolyásoló betegségek, mint például cukorbetegség és más szisztémás betegségek [16]. Nem, vagy rosszul kezelt cukorbetegség esetén, illetve atheroszklerózisban szenvedő betegeknél a periimplantáris szövetek gyulladásának esélye növekszik. A nem vagy rosszul kezelt diabétesz majdnem ugyanolyan erősségü rizikófaktora a periimplantáris gyulladásoknak, mint a dohányzás, emellett nagyban növekszik a periimplantitisz kialakulásának kockázata diabétesz során $[17,18]$. A Nemzetközi Diabetes Szövetség (International Diabetes Federation, IDF) becslése szerint 2017-ben a felnőtt diabéteszes betegek száma 451 millió volt világszerte és ez a szám 2045-re meghaladhatja akár a 693 milliót is [19]. A diabétesz népbetegség, az emberiség nagy részét érintő probléma, tehát a diabétesz szövődményeire és ezek megelőzésére nagy figyelmet kell fordítani. Ebből kifolyólag nagy figyelmet kell szentelni a diabétesz megelőzésének, korai diagnosztizálásának és megfelelő kezelésének, amelyekben nagy segítséget nyújt a laborvizsgálat. A másik sokakat érintő népbetegségnek számító általános megbetegedés, a hiperkoleszterinémia, amely növeli az atheroszklerózis, oszteoporózis és a szív- és érrendszeri betegségek kockázatát, amelyek haláloki jelentősége még mindig a vezető helyen áll a nyugati országokban [20]. Emellett egy kutatásban megfigyelték, hogy a hiperlipidémia fogászati és implantációs szempontból nagy jelentőségű parodontitisznek is kockázati tényezője [21].

Az említettekből kifolyólag fontos a periimplantáris szövődmények elkerülése érdekében, mint primer prevenciós lépés, szűrővizsgálatként laborvizsgálatot végezni, mivel ez nagy szerepet játszhat az egyes rizikófaktorok időben történő kiszűrésében.

Vizsgálatunk célja, hogy a vérvizsgálatot, mint az implantációt megelőző szűrővizsgálat hatékonyságát vizsgáljuk és alkalmazzuk az implantológiában.

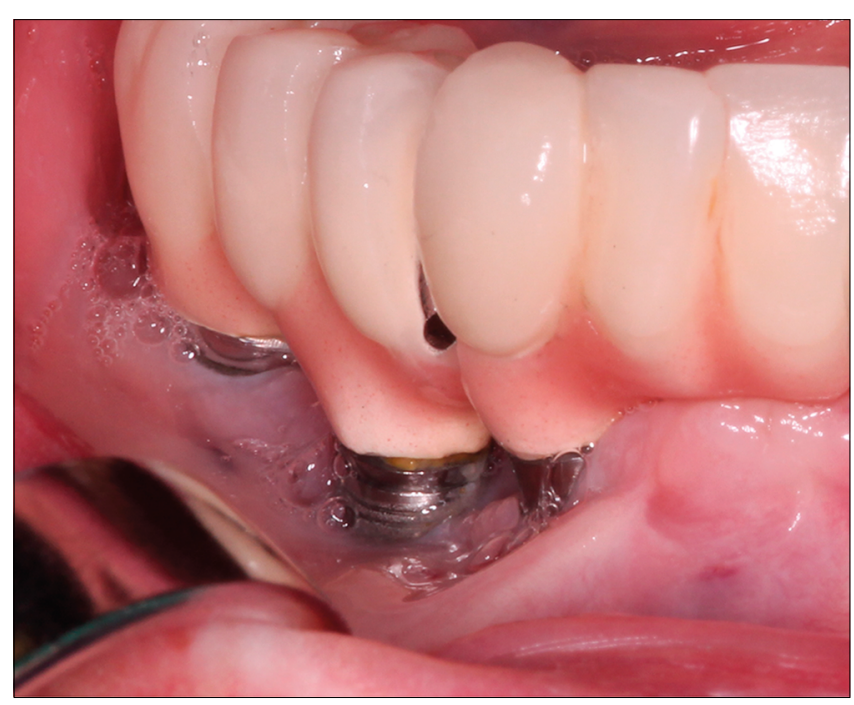

1. ábra: Jobb alsó régióban lévő implantátumoknál jelentkező periimplantitis klinikai képe

\section{Vizsgálati anyag és módszer}

A Fogászati és Szájsebészeti Oktató Intézetben, szűrővizsgálat céljából 33 implantáció előtt álló beteget vizsgáltunk meg. A vizsgált betegek átlagos életkora 62,8 év $( \pm 11)$ volt. Külön a nők átlagos életkora 63,0 év $( \pm 9,9)$, a férfiaké 62,7 év $( \pm 12,6)$ volt (2. ábra). $A$ vizsgálathoz nagyrutin laborvizsgálatot és teljes fogászati státusz felvételét kértük. A vizsgálat során radiológiai vizsgálatokat is végeztünk. A kapott adatokat Microsoft Excel (Remond, Washington, Egyesült Államok) program segítségével kezeltük. Fontos lett volna anamnesztikus adatokat bekérnünk a fogelvesztés okairól, az ilyen jellegű kérdésekre azonban a páciensek nem tudtak válaszolni. Ezért a fogelvesztés okainak tekintetében azokra a vizsgálatokra kell hagyatkoznunk, amelyek a fogelvesztés okaival foglalkoznak. Jelenleg a publikációk [22] többsége a fogelvesztés okainak mintegy 50\%-át jelöli meg káriesz következményes megbetegedéseiként és körülbelül 50\%-át parodontális megbetegedések okaiként. Ez az arány a fejlett ipari országokra jellemző. A kevésbé fejlett országokban a fogelvesztés okai egyharmad részben a káriesz következményes betegségeinek, kétharmad részben a parodontális megbetegedéseknek tudható be. A traumák okozta fogelvesztés, az irradiációt megelőző extrakciók, a csonkolásból adódó fogvesztés stb. százalékos aránya elhanyagolható.

\section{Eredmények}

A vizsgálatban résztvevő betegek 18,2\%-a teljes foghiányos, 81,8\%-a részleges foghiányos páciens volt. A részleges foghiányban szenvedők $66,7 \%$-a volt parodontálisan érintett (3. ábra). A betegek 44,5\%-a mutatott eltérést a gyulladásos paraméterek (vörösvértest 


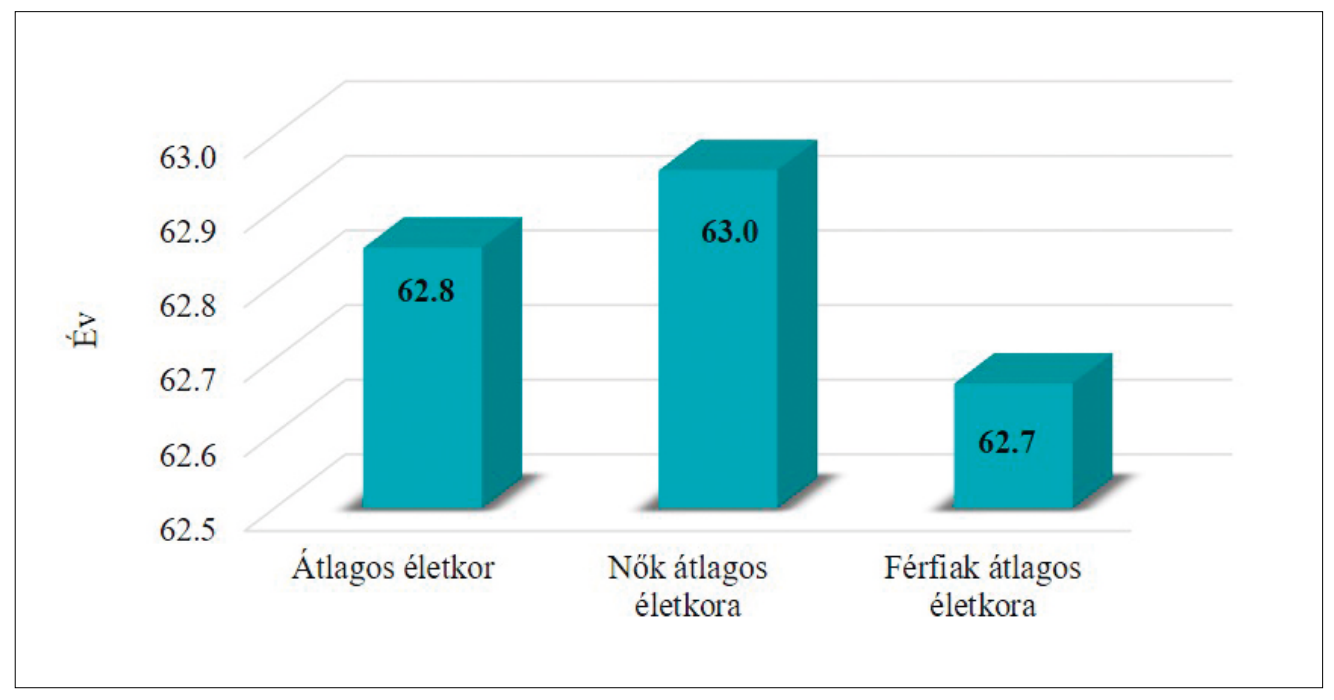

2. ábra: A betegpopuláció átlagos életkora

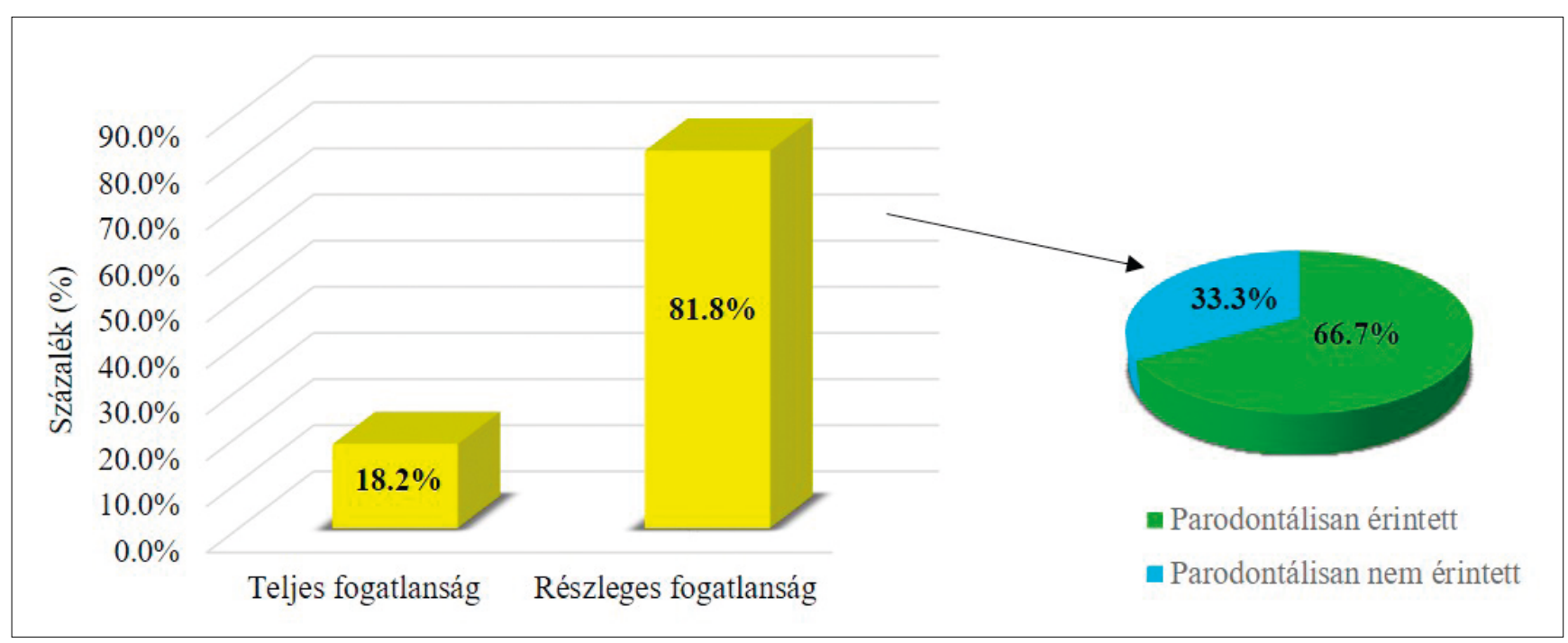

3. ábra: A teljes vagy részlegesen fogatlan páciensek százalékos eloszlása és a parodontális érintettség százalékos eloszlása

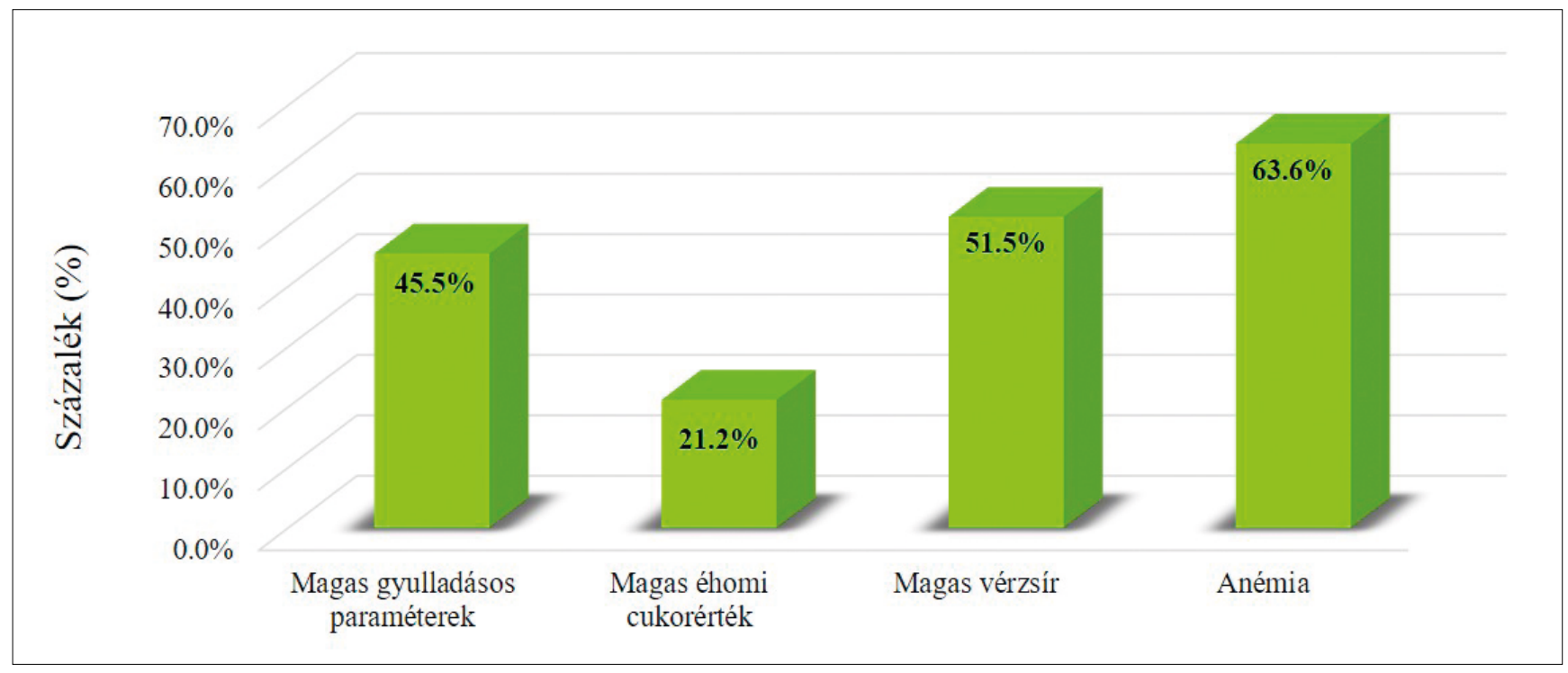

4. ábra: A megemelkedett szérumértékek százalékos viszonylatban 


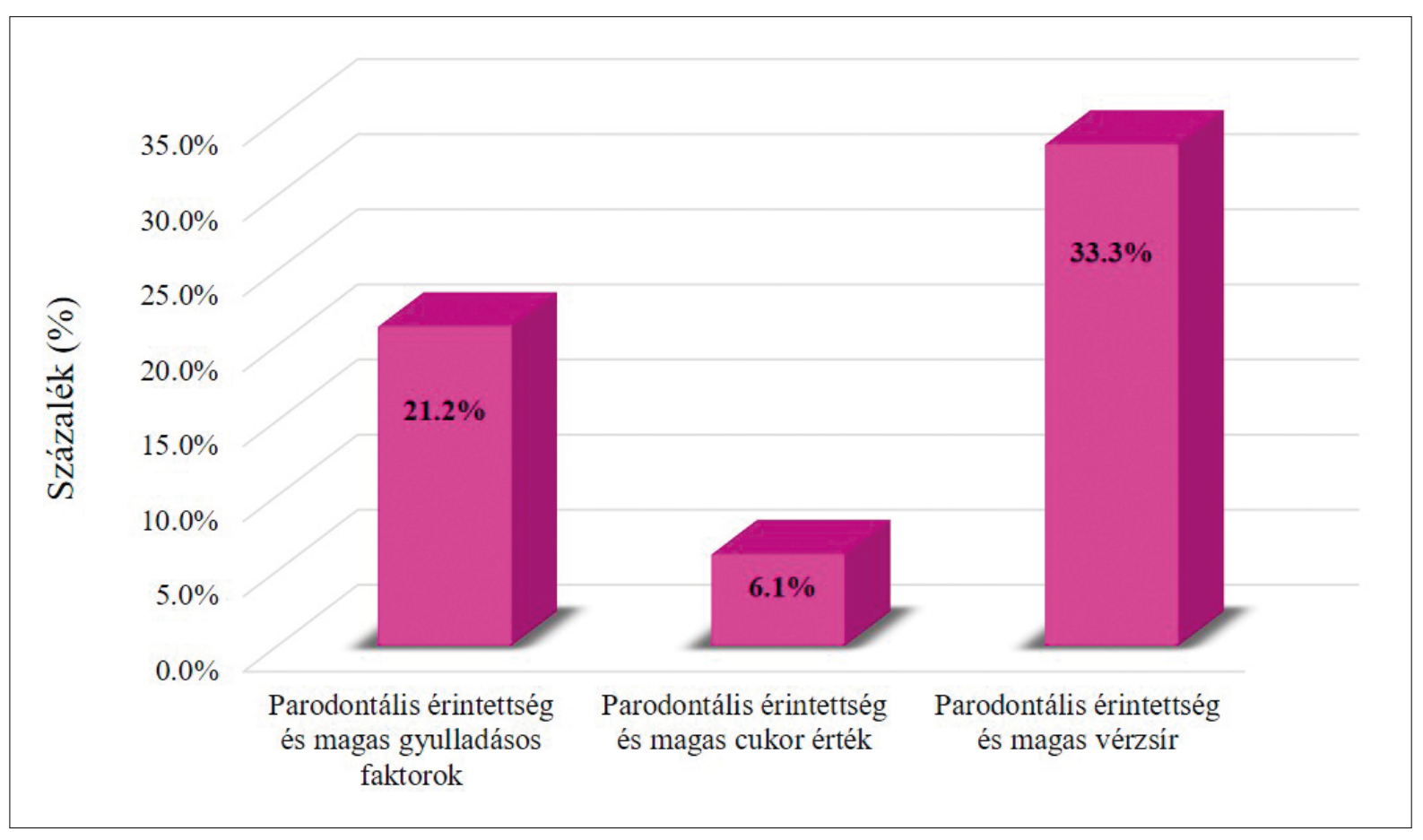

5. ábra: A parodontális érintettség százalékos megoszlásban

süllyedés, C-reaktív protein, fehérvérsejtek mennyiségi és minőségi eltérései) normál értékétől. Különösen fontosnak tartjuk vizsgálni a fehérvérsejt-számot és ezen belül a fehérvérsejtek összetételét, mert ezekből értékes információk vonhatók le az esetleges gyulladások fennállásával kapcsolatban. Ezeknek az adatoknak az elemzése különösen azokban az esetekben kapott nagy jelentőséget, amikor a vérkép elemzését általános szúrővizsgálatként alkalmaztuk és segítségével sikerült kiszúrni még tüneteket nem mutató, de a fehérvérsejtszámban és összetételben jelentkező általános megbetegedéseket. A betegpopuláció 21,2\%-ának volt magas az éhomi vércukorszintje, 51,5\%-nak pedig megnövekedett a vérzsír értéke (összkoleszterin, LDL, triglicerid). A HDL és az LDL értékek elkülönítése azért célszerü, mert éppen fordított módon, ellentétesen hatnak az erek falára lerakódott ateroszklerotikus plakk akkumulációra (4. ábra). Ezek mellett megvizsgáltuk a parodontális érintettség és a laboreltérések együttes előfordulási gyakoriságát is. Magas vércukorszint és a parodontális érintettség együttes előfordulása a betegek 6,1\%-ánál volt megfigyelhető. Míg a betegek 21,2\%-ánál egyszerre volt jelen a parodontális érintettség és a magas gyulladásos paraméter (5. ábra).

\section{Megbeszélés}

A nem vagy rosszul kezelt cukorbetegség rizikófaktora a periimplantáris gyulladások kialakulásának [17]. A cukorbetegségben szenvedők sebgyógyulási hajlama elmarad a nem cukorbeteg társaikétól [23]. Ezekben az esetekben gyakrabban fordul elő $5 \mathrm{~mm}$-nél nagyobb szondázási mélység és magasabb a szondázáskor jelentkező vérzés előfordulása [1]. A hiperlipidémia hozzájárul az atheroszklerózis és az oszteoporózis kialakulásához, így károsítva a kapillárisokat és a csontszerkezetet [24]. Ezáltal negatívan hat a periimplantáris szövetek lokális immunreakciójára és az implantáció hosszútávú sikeressége során nélkülözhetetlen csontintegrációra [25]. Bármely általános rizikófaktor, amely parodontális érintettséggel együtt van jelen, magas rizikót jelent az implantáció során, ezáltal fontos szerep jut ezeknél a pácienseknél a rizikóanalízisnek és a rendszeres kontrollvizsgálatnak.

Nemzetközi publikációk sokasága bizonyítja, hogy meglévő fogak esetében a parodontális státusz részletes felvétele és értékelése meghatározó az azt követő implantológiai beavatkozásokra [26]. A parodontális gyulladások negatívan hatnak az implantációk hoszszútávú sikerességére, hiszen nagy hasonlóságot mutat a parodontitisz és a periimplantitisz esetében előforduló patogén bakteriális flóra. Fontos megjegyezni, hogy a parodontitisznél jelen levő baktériumok akkumulációja az implantátumok porózus felszínén könynyebben megtapad és az implantátumok csavarmenete a gyulladás gyorsabb progresszióját teszi lehetővé. Bár közleményünknek nem direkt témája az implantációt megelőző parodontológiai vizsgálatok elemzése, de ugyanúgy, ahogy véleményünk szerint az implantációt megelőzően minden esetben laborvizsgálatot, vérképanalízist kell végeznünk, ugyanúgy gondos parodontológia vizsgálat elemzésének, értékelésének és kezelésének kell megelőznie az implantációs folyamatot. 
A fogorvosképzésnek két lehetséges formáját ismerjük. Az egyik a DDS (Doctor of Dental Surgery) a másik a DMD (Doctor of Medicine in Dentistry) forma. A DDS képzés lényege, hogy a fogászatot kívülről közelíti az orvosképzéshez. A DDS esetén az úgynevezett „dental school"-ok az orvosegyetemekhez csatlakoztak és így alakult ki a fogorvosi szak, illetve kar. A másik képzési forma, a DMD esetén az orvosegyetemeken belül a speciális oktatási és kutatási követelmények szerint különül el a fogorvostudományi szak és kar. Magyarországon a DMD képzési forma valósult meg, melynek medicinális jellege lényegesen erősebb, mint a DDS képzés esetén. A DMD képzési formában fogorvosaink nem csupán fej-nyak anatómiát, hanem egész test anatómiát tanulnak és a fogorvosok számára rendszeresített belgyógyászat-oktatás felvértezi a fogorvosokat mindazon tudásanyaggal, amely szükséges egy laborlelet elemzéséhez, egy vérkép kiértékeléséhez. Az implantátum behelyezése előtt készített laborleletek kiértékelése nem csupán a korábban említett rizikóanalízis szempontjából kedvező, hanem azért is, mert segítségével számos panaszt nem okozó, de eddig még fel nem ismert, az egész szervezetet érintő megbetegedést sikerül kiszürni.

Álláspontunk szerint, mely a Fogászati és Szájsebészeti Oktató Intézet álláspontja, minden implantáció elött javasolt laborvizsgálat végzése általános egészségi szűrővizsgálatként.

\section{Irodalom}

1. Renvert S, Persson GR, Pirih FQ, Camargo PM: Peri-implant health, peri-implant mucositis, and peri-implantitis: Case definitions and diagnostic considerations. Journal of Clinical Periodontology 2018. Jun; 89 Suppl 1: S304-S312. https://doi.org/10.1002/JPER.17-0588

2. Guillaume B: Dental implants: A review. Morphologie 2016 Dec; 100 (331): 189-198. https://doi.org/10.1016/j.morpho.2016.02.002

3. Hanif A, QuRESH S, SheikH Z, Rashid H: Complications in implant dentistry. Eur J Dent 2017; 11 (1): 135-140. https://doi.org/10.4103/ejd.ejd_340_16

4. Annibali S, Ripari M, La Monaca G, Tonoli F, Cristalli mP: Local complications in dental implant surgery: prevention and treatment. Oral Implantol (Rome) 2008 Apr, 1 (1): 21-33. PMID: 23285333.

5. Almassani AA, ALGhamdi AS: Inferior alveolar nerve injury in implant dentistry: diagnosis, causes, prevention, and management. J Oral Implantol 2010, 36 (5): 401-407. https://doi.org/10.1563/AAID-JOI-D-09-00059

6. Yoon WJ, KIM SG, JeOng MA, OH JS, You JS: Prognosis and evaluation of tooth damage caused by implant fixtures. J Korean Assoc Oral Maxillofac Surg 2013 Jun, 39 (3): 144-147. https://doi.org/10.5125/jkaoms.2013.39.3.144

7. Berglundh T, Armitage G, et al: Periimplant diseases and conditions: Consensus report of workgroup 4 of the 2017 World Workshop on the Classification of Periodontal and Peri-Implant Diseases and Conditions. J Clin Periodontol 2018; 45 (Suppl 20): S286-S291. https://doi.org/10.1111/jcpe.12957

8. Meijer HJ, Raghoebar GM, de Waal YC, Vissink A: Incidence of peri-implant mucositis and peri-implantitis in edentulous patients with an implant-retained mandibular overdenture during a 10-year follow-up period. J Clin Periodontol 2014 Dec; 41 (12): 1178-1183. https://doi.org/10.1111/jcpe.12311
9. Heitz-Mayfield LJA, Salvi GE: Peri-implant mucositis. J Clin Periodontol 2018 Jun; 45 Suppl 20: S237-S245. https://doi.org/10.1111/jcpe.12953

10. Schwarz F, Derks J, Monje A, Wang HL: Peri-implantitis. J Periodontol 2018 Jun; 89 Suppl 1: S267-S290. https://doi.org/10.1002/JPER.16-0350

11. Caton JG, Armitage G, Berglundh T, Chapple IlC, Jepsen $S$, Kornman KS, Mealey BL, Papapanou PN, Sanz M, Tonetti MS1: A new classification scheme for periodontal and peri-implant diseases and conditions - Introduction and key changes from the 1999 classification. J Clin Periodontol 2018 Jun; 45 Suppl 20: S1-S8. https://doi.org/10.1111/jcpe.12935

12. Klinge B, Meyle J and 2. Working Group: Peri-implant tissue destruction. The Third EAO Consensus Conference 2012. Clin Oral Implants Res 2012 Oct; 23 Suppl 6:108-110. https://doi.org/10.1111/j.1600-0501.2012.02555.x

13. Robertson K, Shahbazian T, MacLeod S: Treatment of peri-implantitis and the failing implant. Dent Clin North Am 2015 Apr; 59 (2): 329-343. https://doi.org/10.1016/j.cden.2014.10.007

14. Dreyer H, Grischke J, Tiede $C$, Eberhard J, Schweitzer A, Toikkanen SE, Glöckner S, Krause G, Stiesch M: Epidemiology and risk factors of peri-implantitis: A systematic review. J Periodontal Res 2018; 53 (5): 657-681. https://doi.org/10.1111/jre.12562

15. Patel RM: Dental Implants for Patients with Periodontitis. Prim Dent J 2020 Jan; 29, 8 (4): 54-61. https://doi.org/10.1308/205016820828463898

16. Schwarz F, Derks J, Monje A, Wang HL: Peri-implantitis. $J$ Clin Periodontol 2018. Jun; 45 Suppl 20: S246-S266. https://doi.org/10.1111/jcpe.12954

17. Monje A, Catena A, Borgnakke WS: Association between diabetes mellitus/hyperglycaemia and peri-implant diseases: Systematic review and meta-analysis. J Clin Periodontol 2017. Jun; 44 (6): 636-648. https://doi.org/10.1111/jcpe.12724

18. Naujokat H, Kunzendorf B, Wiltfang J: Dental implants and diabetes mellitus-a systematic review. Int $J$ Implant Dent 2016 Dec; 2 (1): 5. https://doi.org/10.1186/s40729-016-0038-2

19. Cho NH1, Shaw Je2, Karuranga S, Huang Y, da Rocha Fernandes JD, Ohlrogge AW, Malanda B: IDF Diabetes Atlas: Global estimates of diabetes prevalence for 2017 and projections for 2045. Diabetes Res Clin Pract 2018 Apr; 138:271-281. https://doi.org/10.1016/j.diabres.2018.02.023

20. G VAN Camp: Cardiovascular disease prevention. Acta Clin Belg 2014 Dec; 69 (6): 407-411. https://doi.org/10.1179/2295333714Y.0000000069

21. Katz J, Chaushu G, Sharabi Y: On the association between hypercholesterolemia, cardiovascular disease and severe periodontal disease. J Clin Periodontol 2001 Sep; 28 (9): 865-868. https://doi.org/10.1034/j.1600-051x.2001.028009865.x

22. Phipps KR, Stevens VJ: Relative contribution of caries and periodontal disease in adult tooth loss for an HMO dental population. J Public Health Dent 1995. https://doi.org/10.1111/j.1752-7325.1995.tb02377.x

23. Novotna M, Podzimek S, Broukal Z, Lencova E, Duskova J: Periodontal Diseases and Dental Caries in Children with Type 1 Diabetes Mellitus. Mediators Inflamm 2014., 2015; 379626. https://doi.org/10.1155/2015/379626

24. GITT AK, ZAHN R: Hypercholesterolemia - Where are we today? Where are we going? Herz 41 (5): 413-420. https://doi.org/10.1007/s00059-016-4457-x

25. Waskiewicz K, Oth O, Kochan N, Evrard L: Risk factors generally neglected in oral surgery and implantology: the high LDL-cholesterol and the insufficient level of vitamin D. Rev Med Brux 2018; 39 (2): 70-77. https://doi.org/10.30637/2018.17-075

26. Sung CE, Chiang CY, Chiu HC, Shieh YS, Lin FG, Fu E: Periodontal status of tooth adjacent to implant with peri-implantitis. J Dent 2018 Mar. https://doi.org/10.1016/j.jdent.2018.01.004 


\begin{abstract}
Nagy-Csoma L, IVÁnYıD, Kivovics P, Németh O

\section{Relevance of blood tests before dental implantation}

Nowadays, dental implantation is increasingly common intervention in dentistry. With the spread of implantations, implantrelated complications are coming into view. Biological complications include peri-implant mucositis and peri-implantitis. General risk factors for peri-implant inflammation include diseases, such as diabetes mellitus and hyperlipidemia. The aim of this study is to examine the efficiency of blood tests before implantation, as a preventive screening method of implantation and its application in the prevention of peri-implant inflammations. 33 patients' dental statuses and blood tests were collected. We analysed our data by Microsoft Excel program (Remond, Washington, USA). The patients' average age was $62,8( \pm 11) .81,8 \%$ of the patients were partial edentulous and $66,7 \%$ of partial edentulous patients had periodontal involvement. $21,2 \%$ of the observed patients had high blood sugar level, $51,5 \%$ of them had elevated blood lipid level. We further examined the association between the prevalence of blood tests' deviation and the prevalence of periodontal involvement. High blood sugar level and periodontal involvement simultaneously occurred in 6,1\% and periodontal involvement with increased inflammatory factors were noticed in $21,2 \%$ of the patients. Untreated or not properly treated diabetes mellitus is a risk factor of peri-implant inflammation. Hyperlipidemia has negative effects on the local immune response of peri-implant tissues and osseointegration, which influence the long-term success of the implantation. All of the general risk factors with periodontal involvement increased the risk for peri-implant diseases and therefore we have to make risk analysis and regular controls. The blood-test, according to the Department of Community Dentistry, is a suitable and sufficient method to detect general risk factors before implantation.
\end{abstract}

Keywords: Blood test, dental implantation, peri-implantitis, primer prevention, diabetes mellitus, hyperlipidemia 